\title{
Metabolic engineering of Saccharomyces cerevisiae for optimizing 3HP production
}

\author{
Jensen, Niels Bjerg; Maury, Jerome; Oberg, Fredrik; Kildegaard, Kanchana Rueksomtawin; Forster, \\ Jochen; Nielsen, Jens; Borodina, Irina
}

Published in:

New Biotechnology

Link to article, DOI:

10.1016/j.nbt.2012.08.170

Publication date:

2012

Document Version

Publisher's PDF, also known as Version of record

Link back to DTU Orbit

Citation (APA):

Jensen, N. B., Maury, J., Oberg, F., Kildegaard, K. R., Forster, J., Nielsen, J., \& Borodina, I. (2012). Metabolic engineering of Saccharomyces cerevisiae for optimizing 3HP production. New Biotechnology, 29s, s61. https://doi.org/10.1016/j.nbt.2012.08.170

\section{General rights}

Copyright and moral rights for the publications made accessible in the public portal are retained by the authors and/or other copyright owners and it is a condition of accessing publications that users recognise and abide by the legal requirements associated with these rights.

- Users may download and print one copy of any publication from the public portal for the purpose of private study or research.

- You may not further distribute the material or use it for any profit-making activity or commercial gain

- You may freely distribute the URL identifying the publication in the public portal 
ical capabilities to thrive in extreme habitats, therefore marine habitat provides a magnificent opportunity to discover newer compounds such biosurfactants (BS) and bioemulsifiers (BE). The aim of this study was the screening of marine bacteria able to produce biosurfactants from cheap carbon sources. Fifty-eight bacterial isolates obtained from marine invertebrates were evaluated for biosurfactant/bioemulsifier production in liquid medium using glycerol, sucrose, mineral oil and soybean oil as carbon sources. The surfactant production was evaluated by the measurements of the surface tension of cell-free culture broth and the emulsifier ability by the drop-collapse technique. Sixteen isolates were preselected for their ability to produce $\mathrm{BS} / \mathrm{BE}$, three isolates showed surface tension of $35-40 \mathrm{mN} / \mathrm{m}$ and other three isolates showed the lowest surface tension values. The best results were obtained with an Arthrobacter sp. growing in soybean oil (ST $29.1 \mathrm{mN} / \mathrm{m}$ ), Brevibacterium luteolum in mineral oil (ST $28.9 \mathrm{mN} / \mathrm{m}$ ) and Gordonia sp. in soybean oil (ST $31.4 \mathrm{mN} / \mathrm{m}$ ). The hydrophobic carbon sources were the preferred substrates for BS production by the marine bacteria.

http://dx.doi.org/10.1016/j.nbt.2012.08.168

Poster 1.3.24

Protein encapsulation by biosilification catalyzed by glutathione S-transferase (GST)-silicatein

Mi-Ran Ki*, Bashistha Kumar Kanth, Ki Ha Min, Ki Baek Yeo, Eui Kyoung Jang, Seung Pil Pack*

Department of Biotechnology and Bioinformatics, Korea University, Sejong 339-700, Republic of Korea

A protein of sponge, called silicatein, can catalyze silica deposition in vitro under near neutral $\mathrm{pH}$ and ambient temperature condition. This biosilification process therefore has attracted much interest as a promising system to gain silica-based nanostructures or materials at environmentally benign condition. Since the yield of recombinant silicatein as a soluble form was low, we tried to improve that by employing E. coli based codon usage and fusion protein system. GST fusion proteins not only act as solubility enhancing partners but also offer an important biological assay for direct protein-to-protein interactions. The soluble expression of silicatein was enhanced by two folds when expressed as a GST fusion protein in E. coli. Furthermore, this fusion protein was immobilized on glutathione (GSH)-coated plate via GST-tag and remained active to form silica layer on surface by means of biosilification in the presence of tetraethyl orthosilicate as substrate at an ambient temperature and neutral $\mathrm{pH}$. Simultaneously, green fluorescent protein or horseradish peroxidase enzyme was immobilized on silica surface by simple adding it during biosilification. Immobilized proteins retained their activity and were released gradually. This technique can be applied to form biocompatible silica coating for catalytic, diagnostic and sensing surface, and matrix for tissue cultures.

Keywords: Silicatein; GST-fusion protein; Biosilification; Enzyme immobilization

http://dx.doi.org/10.1016/j.nbt.2012.08.169

\section{Poster 1.3.25}

Metabolic engineering of Saccharomyces cerevisiae for optimizing 3HP production

Niels Bjerg Jensen*, Jerome Maury, Fredrik Oberg, Kanchana Rueksomtawin Kildegaard, Jochen Forster, Jens Nielsen, Irina Borodina

NNF Center for Biosustainability, Technical University of Denmark, Hørsholm, Denmark

The finite nature of fossil resources and the negative influence of $\mathrm{CO}_{2}$ emissions on the global climate are key drivers in development of new biological processes. These are based on renewable resources such as sugar, starch, and biomass and aim at replacing chemical production from fossil fuels. Polyacrylates are a substantial part of the different plastic varieties found on the market. This kind of plastic is derived from acrylic acid, which is currently produced from propylene, a by-product of ethylene and gasoline production. Annually, more than one billion kilograms of acrylic acid is produced and the market for acrylate products exceeds USD 100 billion.

As an alternative to oil and gas derived acrylic acid, 3hydroxypropionic (3HP) acid produced from renewable sources is highly desired, because $3 \mathrm{HP}$ can easily be converted into acrylic acid. We are setting out to produce 3HP in yeast Saccharomyces cerevisiae. One main reason for selecting Baker's yeast as host organism is that yeast has a high tolerance towards low $\mathrm{pH}$ in comparison to bacteria, e.g. E. coli. Hence, it lowers the consumption of base for neutralization of growth media when compared to bacteria. The preferred engineered pathway towards 3HP has a substantial need for NADPH equivalents. Consequently, a yeast host with elevated NADPH availability is preferred. We will redirect several of the glycolysis steps in order to increase the NADPH generation per glucose molecule and thereby increase $3 \mathrm{HP}$ production.

We believe this strain will be of high interest for other NADPH demanding biosynthetic routes.

http://dx.doi.org/10.1016/j.nbt.2012.08.170

\section{Poster 1.3.26}

Peptide affinity to $\mathrm{TiO}_{2}$ is necessary but not sufficient for prediction of its biomineralizing efficacy

Noori Choi ${ }^{1, *}$, Young Jun $\mathrm{Kim}^{2}$, Chang-Hoon $\mathrm{Nam}^{2}$, Minjin $\mathrm{Cha}^{1}$, Woo-Seok Choe ${ }^{1,3}$

${ }^{1}$ SKKU Advanced Institute of Nanotechnology (SAINT), Sungkyunkwan University, Suwon 440-746, Republic of Korea

${ }^{2}$ Nanomedicine, KIST-Europe, Saarbrucken 66123, Germany

${ }^{3}$ School of Chemical Engineering, Sungkyunkwan University, Suwon 440-746, Republic of Korea

Using cyclic constrained $\mathrm{TiO}_{2}$ binding peptides STB1 (CHKKPSKSC), RSTB1 (CHRRPSRSC) and linear peptide LSTB1 (AHKKPSKSA), it was shown that while affinity of the peptide to $\mathrm{TiO}_{2}$ is essential to enable $\mathrm{TiO}_{2}$ biomineralization, other factors such as biomineralization kinetics and peptide local structure need to be considered to predict biomineralization efficacy. Cyclic and linear $\mathrm{TiO}_{2}$ binding peptides show significantly different 